\title{
Mangroves in peril: unprecedented degradation rates of peri-urban mangroves in Kenya
}

\author{
J. O. Bosire ${ }^{1,6}$, J. J. Kaino ${ }^{2}$, A. O. Olagoke ${ }^{3,4}$, L. M. Mwihaki ${ }^{2}$, G. M. Ogendi ${ }^{2}$, J. G. Kairo ${ }^{1}$, U. Berger ${ }^{3}$, and \\ D. Macharia ${ }^{5}$ \\ ${ }^{1}$ Kenya Marine and Fisheries Research Institute, P.O. Box 81651-80100, Mombasa, Kenya \\ ${ }^{2}$ Department of Environmental Science, Egerton University, P.O. Box 536-20115, Egerton, Kenya \\ ${ }^{3}$ Institute of Forest Growth and Forest Computer Sciences, Faculty of Environmental Sciences, Technische Universität \\ Dresden, Postfach 1117, 01735 Tharandt, Germany \\ ${ }^{4}$ Federal University of Technology, Department of Forestry and Wood Technology, P.M.B. 704, Akure, Nigeria \\ ${ }^{5}$ Regional Centre for Mapping of Resources for Development, P.O. Box 632-00618, Nairobi, Kenya \\ ${ }^{6}$ World Wide Fund for Nature (WWF), P.O. Box 62440-00200, Nairobi, Kenya
}

Correspondence to: J. O. Bosire (jbosire@kmfri.co.ke)

Received: 11 June 2013 - Published in Biogeosciences Discuss.: 24 October 2013

Revised: 9 March 2014 - Accepted: 16 March 2014 - Published: 16 May 2014

\begin{abstract}
Marine ecosystems are experiencing unprecedented degradation rates higher than any other ecosystem on the planet, which in some instances are up to 4 times those of rainforests. Mangrove ecosystems have especially been impacted by compounded anthropogenic pressures leading to significant cover reductions of between 35 and $50 \%$ (equivalent to 1-2\% loss pa) for the last half century. The main objective of this study was to test the hypothesis that peri-urban mangroves suffering from compounded and intense pressures may be experiencing higher degradation rates than the global mean (and/or national mean for Kenya) using Mombasa mangroves (comprising Tudor and Mwache creeks) as a case study. Stratified sampling was used to sample along 22 and 10 belt transects in Mwache and Tudor respectively, set to capture stand heterogeneity in terms of species composition and structure in addition to perceived human pressure gradients using proximity to human habitations as a proxy. We acquired SPOT (HRV/ HRVIR/ HRS) images of April 1994, May 2000 and January 2009 and a vector mangrove map of 1992 at a scale of $1: 50000$ for cover change and species composition analysis. Results from image classification of the 2009 image had $80.23 \%$ overall accuracy and Cohen's kappa of 0.77 , thus proving satisfactory for use in this context. Structural data indicate that complexity index (CI) which captures stand structural development was higher in Mwache at 1.80 compared to Tudor at 1.71. From
\end{abstract}

cover change data, Tudor lost $86.9 \%$ of the forest between 1992 and 2009, compared to Mwache at 45.4\%, representing very high hitherto undocumented degradation rates of 5.1 and $2.7 \%$ pa respectively. These unprecedentedly high degradation rates, which far exceed not only the national mean (for Kenya of $0.7 \%$ pa) but the global mean as well, strongly suggest that these mangroves are highly threatened due to compounded pressures. Strengthening of governance regimes through enforcement and compliance to halt illegal wood extraction, improvement of land-use practices upstream to reduce soil erosion, restoration in areas where natural regeneration has been impaired, provision of alternative energy sources/building materials and a complete moratorium on wood extraction especially in Tudor Creek to allow recovery are some of the suggested management interventions.

\section{Introduction}

Marine ecosystems are experiencing unprecedented degradation rates higher than any other ecosystem on the planet. In some instances, they are up to 4 times those of rainforests. Currently between 2 and $7 \%$ of these ecosystems are lost annually, a seven-fold increase compared to only half a century ago (Nelleman et al., 2009). Mangrove ecosys- 
tems have especially been impacted by anthropogenic pressures like unsustainable wood harvesting, sewage discharge, dredging, conversion for agriculture, shrimp farming, land development and unplanned development, leading to significant cover reductions of between 35 and $50 \%$ for the last half century (Valiela et al., 2001, Alongi, 2002; Duke et al., 2007; Giri et al., 2011). Consequences of this widespread degradation include biomass loss and increased carbon emissions (Donato et al., 2011), alteration of forest structure, change in species composition (Kairo et al., 2002; Bosire et al., 2003, 2006), reduced fisheries production and aggravated coastal erosion (Rönnbäck, 1999; Nageikerken et al., 2002; Alongi, 2008; Zhang et al., 2012) among others. As human activities continue to expand in coastal environments with escalating world population, the likelihood of increasing magnitude of such impacts is foreseeable.

Additionally, climate change impacts have further compounded pressure on mangrove forests. They include sea level rise, flooding, erosion and sedimentation, fluctuating precipitation and temperature regimes, and associated phenomena like hurricanes and cyclones among others (McLeod and Salim, 2006; IPCC, 2007; Gilman et al., 2008; Bosire, 2010; Bosire et al., 2012). These extreme events will be more frequent and thus impact ecosystems. An example is the Indian Ocean Dipole (IOD), which caused flooding and massive sedimentation in 1997-1998 and 2006 in the region, leading to mangrove die-back in several places (Kitheka et al., 2002; Wieczkowski, 2009). IOD, described as unique to the Indian Ocean, is a distinct coupled oscillation in oceanatmosphere interactions, controlling sea surface temperature (SST) anomalies (Saji et al., 1999, 2006). This phenomenon occurs in phase or out phase with El Niño-Southern Oscillation (ENSO) (Kayanne et al., 2006; Marchant et al., 2006; Pillai and Mohankumar, 2010) and causes warmerthan-normal SSTs in the western basins but cooler SSTs in the eastern basins.

Although the concomitant impacts of climate-related phenomena on mangrove forests might vary in different localities (Ellison and Stoddart, 1991; Twilley, 1998; Allen et al., 2001), the risk of more costly climate-driven ecological feedbacks to mangrove forests with changing climate is probable; this necessitates studies oriented at understanding mangrove vulnerability and resilience to climate-driven disturbances at the local, regional and global scale. Hitherto, the long-term impacts of climate-related disturbances on mangrove ecosystems still remain unclear.

Remote sensing has been identified as an effective tool to study otherwise difficult-to-reach and difficult-to-penetrate mangroves along coastal areas. Landsat and SPOT images have been used for visual interpretation (Gang and Agatsiva, 1992), determining vegetation index (Blasco et al., 1986; Chaudhury 1990; Jensen et al., 1991), classification (Aschbacher et al., 1995), and band rationing (Long and Skewes, 1994) of all types of mangrove vegetation. Remote sensing applications have been applied mainly for mangrove in- ventory, mapping, and change detection. Landsat and SPOT data, as well as high spatial resolution airborne multispectral and SIR-C radar data, have also been used for management purposes in a number of countries (Gang and Agatsiva, 1992; Gao 1998; Green et al., 1998; Kairo et al., 2002). Nevertheless, remote sensing techniques applied to mangrove vegetation are still not as common as for terrestrial systems, particularly along the east coast of Africa (Blasco et al., 1994; Dale et al., 1996).

Although the global mean annual cover loss of mangroves has been estimated at 1-2\% (Alongi, 2002; Duke et al., 2007; Giri et al., 2011), it is highly probable that this global estimate does not capture local rates in many places, which may be higher than previously perceived. Recent assessment in Kenya revealed that the country's mangroves have experienced a $20 \%$ loss over a period of 25 years (1985-2010), representing an annual loss of $0.74 \%$ (Kirui et al., 2013). This study suggested that the Kenyan mangroves are falling below the global mean in terms of annual cover loss. However, the risk of using such averaged measures is a misleading perception of the real situation, which may compromise necessary management interventions. Consequently, this study seeks to assess the spatio-temporal dynamics of most periurban mangroves in Kenya with a hypothesis that they are experiencing much higher degradation rates than the reported national and/or global rates. Peri-urban as used here refers to mangroves adjacent to a city.

\section{Materials and methods}

\subsection{Site description}

The study was undertaken in two mangrove forests of Tudor and Mwache creeks (Fig. 1), Mombasa, in the coastal province of Kenya. Tudor Creek $\left(4^{\circ} 2^{\prime} \mathrm{S}, 39^{\circ} 40^{\prime} \mathrm{E}\right)$, located at the northwest of Mombasa island, extends some 10-15 km inland with two main seasonal rivers, Kombeni and Tsalu, draining over 45000 and 10000 ha respectively. The creek is characterized by a $20 \mathrm{~m}$ mean depth single narrow sinuous inlet that widens inland to a central $5 \mathrm{~m}$ depth basin, covering an area of 637 and 2235 ha at low and high water spring tides respectively (Omar et al., 2008); and an average tidal range of 0.6 and $4.5 \mathrm{~m}$, in the respective neap and spring tides. Within the creek is a mangrove forest, extending over an area of 1641 ha, principally composed of Rhizophora mucronata Lamk., Sonneratia alba J. Smith., and Avicennia marina (Forsk.) Vierh. and has no display of distinct species zonation along the tidal gradient (Macnae, 1968; Gallin et al., 1989; Ruwa, 1992). The forest is covered by sediments that are predominantly made up of mud, and sand in some parts (Omar et al., 2008).

Mwache Creek $\left(4^{\circ} 3.01^{\prime} \mathrm{S}, 39.06^{\circ} 38.06^{\prime} \mathrm{E}\right)$ is located $20 \mathrm{~km}$ northwest of Mombasa Island (Fig. 1). The total area of the wetland is approximately 1500 ha with about 


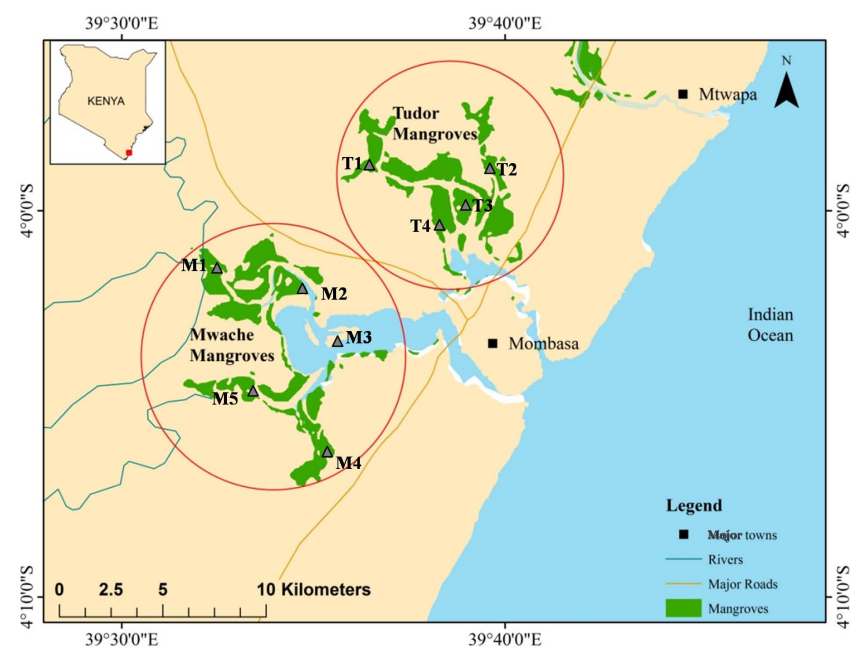

Fig. 1. Map of the study area showing the Mombasa mangroves (Mwache and Tudor creeks): M1, M2, M3, M4 and M5 represent Mashazani, Ngare, KPA, Mwakuzimu and Maguzoni respectively (in Mwache Creek), whereas T1, T2, T3 and T4 represent Jomvu, Kijiwe, Island and Mikindani respectively (in Tudor Creek).

$70 \%$ of the surface area being covered with mangroves, comprised of both basin and riverine mangroves, according to the physiographic classification proposed by Lugo and Snedaker (1974). The dominant mangrove species in Mwache are A. marina, R. mucronata, Ceriops tagal (Perr.) C. B. Rob., and S. alba (Kitheka et al., 2002). The creek receives freshwater from Mwache River, which is seasonal, and thus there is usually no flow during the dry season especially between December and March, and July and September. The rate of sediment production within Mwache River basin reaches a high of 3000 tonnes per year due to poor land-use activities upstream, high rainfall intensity during the rainy season and steep land gradient (Kitheka et al., 2002; Bosire et al., 2006).

Characterizing the climate of both creeks is the influence of semi-annual passage of the Intertropical Convergence Zone (ITCZ) and the monsoons in two distinct seasons. The north-easterly monsoon (NEM) manifests between December and March, and the south-easterly monsoon (SEM) is experienced between May and October. The mean annual rainfall is about $1038 \mathrm{~mm}$, with peaks in May and June; the mean annual temperatures are $23.9^{\circ} \mathrm{C}$ and $28.5^{\circ} \mathrm{C}$, for the rainy and dry seasons respectively (Obura, 2001; Omar et al., 2008).

\subsection{Sampling methods}

\subsubsection{Vegetation structure and species composition}

Data on mangroves structure and species composition were acquired using stratified sampling technique (Cintron and Schaeffer-Novelli, 1984). Sampling transects perpendicular to the shoreline were identified prior to field campaigns using unsupervised classified SPOT images of 2009. The locations of the different transects were determined based on observed vegetation classes, canopy cover and length of intertidal area so as to capture different plant assemblages as representatives for the whole forest. Vegetation sampling were carried out using standard $10 \mathrm{~m} \times 10 \mathrm{~m}$ quadrats that were laid $100 \mathrm{~m}$ away from each other perpendicularly along the transect lines in the forest. Stratified sampling was used to sample along 22 and 10 belt transects in Mwache and Tudor respectively, set to capture stand heterogeneity in terms of species composition and structure in addition to perceived human pressure gradients using proximity (or otherwise) to human habitations as a proxy.

Within each quadrat, tree height, stem diameter and crown diameter for all the trees greater than $2.5 \mathrm{~cm}$ diameter were determined. Tree height was measured using a Suunto hypsometer, while DBH (diameter at breast height) was measured using forest calipers. Consequently, information on the composition, diversity, structural parameters and community indices (basal area, stem density, complexity index, importance value index) were computed, together with diameter size class distribution and height profile, to describe the structure and composition of the forest.

$\mathrm{BA}=\frac{\pi \mathrm{DBH}^{2}}{4} \mathrm{~cm}^{2}$, where, $\pi=3.142$

Importance value index, describing the structural role of individual tree species in the habitat, was calculated following Husch et al. (2003):

$\mathrm{IV}_{j}=$ relative density

+ relative dominance + relative frequency,

Relative density $=100 \times\left(\frac{d_{j}}{D}\right)$,

Relative dominance $=100 \times\left(\frac{x_{j}}{X}\right)$,

Relative frequency $=100 \times\left(\frac{n_{j}}{N}\right)$,

where $\mathrm{IV}_{j}$ represents importance value of $j$ th species; $d_{j}$ represents number of individuals of the $j$ th species present in the sample population (density), where $D$ is the total number of individuals in the sample population $(D=\Sigma) ; x_{j}$ represents the sum of basal area for $j$ th species (dominance), where $X$ is the total of basal area across all species $(X=\Sigma)$; and $n_{j}$ represents the number of sampling units where $j$ th species are present (occurrence), wherein $N$ is the total number of sampling units. 
Importance value (IV) of each species was calculated by summing its relative density, relative frequency and relative dominance so as to get relative contribution of each species to the overall stand structure. Stand complexity index (CI) was calculated according to Holdridge et al. (1971). This index is used to illustrate how complex or structurally developed a stand is and is derived from combining all the measured stand structural attributes (stem density (number of stems $/ 0.1$ ha $\times 10-3$ in a 0.1 ha plot), $D_{130}$ calculated into basal area $\left(\mathrm{m}^{2} / 0.1 \mathrm{ha}\right)$, height $(\mathrm{m})$ and number of a species).

$\mathrm{CI}=s \times d \times \bar{h} \times \mathrm{BA} \times 10^{-5}$,

where $s$ is number of species; $d$ is stand density; $h$ is mean height; and BA is basal area

\subsubsection{Natural regeneration}

Data on the composition and distribution pattern of natural regeneration were obtained using the method of linear regeneration sampling (Sukardjo, 1987; FAO, 1994; Kairo et al., 2002), which was used to sample all juveniles in $5 \mathrm{~m} \times 5 \mathrm{~m}$ subplots (within the main $10 \mathrm{~m} \times 10 \mathrm{~m}$ quadrats). According to Stoddard and Stoddard (1987) occurrence of all trees of different species with diameter less than $2.5 \mathrm{~cm}$, classified as juveniles, was recorded and grouped according to their regeneration classes based on height. Seedlings $<40 \mathrm{~cm}$ were classified as regeneration class I (RCI). Saplings between 40 and $150 \mathrm{~cm}$ height were classified as RCII, and RCIII was for all small trees with heights $>150 \mathrm{~cm}$ but $<2.5 \mathrm{~cm} \mathrm{DBH}$.

\subsubsection{Mangrove cover change detection}

\subsection{Image processing}

We acquired SPOT (HRV/HRVIR/HRS) of April 1994, May 2000 and January 2009 and a vector mangrove map of 1992 at a scale of 1:50000 from a mapping project done by the Food and Agriculture Organization (FAO, 1992). This map was an interpretation from aerial photographs. The map provided a validated baseline from which to detect future changes (Kirui et al., 2013). Both 1994 and 2000 images had a ground resolution of $20 \mathrm{~m}$, while the 2009 image had a ground resolution of $5 \mathrm{~m}$ pan-sharpened to $2.5 \mathrm{~m}$ resolution. Image classifications were done on the composites of the three SPOT images with each containing the three primary bands (B1 (green), B2 (red) and B3 (near infrared, or NIR). The band combination (false colour) for these was 32-1 for NIR (B3), red (B2) and green (B1); the datum used for the GPS was WGS 84 (World Geodetic System 1984).

All image processing was done using ENVI + IDL 4.72, while ArcGIS 9.3 was used to create final maps and to compute statistics. All the images were registered to WGS 84 UTM zone 37S projection. We adopted the nearestneighbour re-sampling method (Reddy and Roy, 2008; Ardli and Wolff, 2009) for geometric correction of the $2009 \mathrm{im}$ age, with a resultant root mean square error (RMSE) of half pixel which is approximately $1.25 \mathrm{~m}$. This was an acceptable error for subsequent image analysis. A pre-registered Landsat image of the study area obtained in 2003 was used as the source for ground control points for correcting the $2009 \mathrm{im}$ age. Consequently, a feature-based image-image registration was applied to both 1994 and 2000 images as the warp images and 2009 as the base image in order to align the two images with the base image. Four reference points identified from the 2009 image were used as control points for subsequent registration of the 1994 and 2009 images. The resultant RMSEs were $1(20 \mathrm{~m})$ and $1.5(30 \mathrm{~m})$ pixels respectively. Since change detection was entirely based on comparative post-classification direct analysis between the total mangrove cover for the four time steps, these errors were deemed sufficient in this context. This comparison involved converting the resultant raster classes into vector in order to compare with the 1992 baseline map. Before classifications, dark object subtraction, using the atmospheric correction method (Song et al., 2001), was later done on the three images to remove effects of the different atmospheric conditions on the reflectance for the three images taken at different temporal resolutions.

\subsection{Mangrove forest mapping and cover change analysis}

ISODATA and K-means unsupervised classification methods were separately done on the 2009 image prior to fieldwork. These classifications were set to retrieve 26 different spectral classes for comparison of the best-result-yielding method. The K-means method was found most suitable for field campaign as it clearly delineated major mangrove zones. These were later grouped into nine broad informational classes after close expert knowledge examination. This helped identify regions of interest (ROI), collection of ground control points (GCPs) and delineation of training sites for supervised classifications. Rigorous field campaigns were done at a cross section of main mangrove species aggregation area. Ground control points were collected using a Garmin GPS 76 in UTM coordinates. This model had between 5 and $10 \mathrm{~m}$ positional accuracy. To minimize errors resulting from the GPS accuracy, we ensured that collected GCPs were within a $10 \mathrm{~m}$ radius of the same land cover type.

We identified eight main classes representing the four main mangrove species in the area (Rhizophora mucronata, Avicennia marina, Ceriops tagal and Sonneratia alba), mud, sand, water and terrestrial areas to map mangroves to species level using the 2009 high-resolution image. Due to their coarse ground resolution, the 1994 and 2000 images were not suitable to map mangroves to species level; hence the images were only classified to two broad categories: mangrove areas and non-mangrove areas. Training sites were later digitized by overlaying the GCPs on the three images and creating 
Table 1. Structural characteristics of Tudor and Mwache mangroves.

\begin{tabular}{lllllll}
\hline \multirow{2}{*}{ Parameters } & \multicolumn{2}{c}{ Summary of structural attributes of mangrove vegetation in Mwache Creek } & \\
Mwakuzimu & Ngare & Mashazani & Maguzoni & Islands & All sub-sites \\
\hline Number of species & 5 & 4 & 4 & 3 & 1 & 5 \\
Mean DBH (cm) & $9.90 \pm 0.37^{\mathrm{a}}$ & $12.95 \pm 0.57^{\mathrm{b}}$ & $8.82 \pm 0.40^{\mathrm{a}}$ & $6.40 \pm 0.46^{\mathrm{c}}$ & $10.07 \pm 0.46^{\mathrm{a}}$ & $6 . \pm 1.064$ \\
Mean height (m) & $5.5 \pm 1.3^{\mathrm{a}}$ & $6.4 \pm 0.8^{\mathrm{a}}$ & $4.8 \pm 0.4^{\mathrm{a}}$ & $4.6 \pm 0.7^{\mathrm{a}}$ & $6.2 \pm 0.6^{\mathrm{a}}$ & $5.3 \pm 2.4$ \\
Stand density (stems ha $\left.^{-1}\right)$ & $1840 \pm 22^{\mathrm{a}}$ & $1448 \pm 18^{\mathrm{a}}$ & $84 \pm 9^{\mathrm{b}}$ & $2633 \pm 44^{\mathrm{a}}$ & 2000 & $1701 \pm 105$ \\
BA $^{2} \mathrm{ma}^{-1}$ ) & $4.2 \pm 2.1^{\mathrm{b}}$ & $6.9 \pm 3.5^{\mathrm{b}}$ & $0.2 \pm 0.1^{\mathrm{c}}$ & $5.1 \pm 2.1^{\mathrm{b}}$ & $19.3^{\mathrm{a}}$ & $4.0 \pm 0.2$ \\
Complexity index (CI) & 2.13 & 2.56 & 0.003 & 1.85 & 2.39 & 1.80 \\
\hline
\end{tabular}

\begin{tabular}{|c|c|c|c|c|c|}
\hline \multicolumn{6}{|c|}{ Summary of structural attributes of mangrove vegetation in Tudor Creek } \\
\hline Parameters & Mikindani & Islands & Jomvu & Kijiwe & All sub-sites \\
\hline Number of species & 3 & 3 & 5 & 3 & 5 \\
\hline Mean DBH $(\mathrm{cm})$ & $5.04 \pm 0.53^{\mathrm{a}}$ & $7.67 \pm 0.38^{b}$ & $7.75 \pm 2.77^{\mathrm{b}}$ & $4.43 \pm 0.66^{\mathrm{a}}$ & $6.35 \pm 0.1$ \\
\hline Mean height (m) & $3.43 \pm 0.48^{\mathrm{a}}$ & $4.43 \pm 0.27^{\mathrm{b}}$ & $5.45 \pm 1.12^{\mathrm{b}}$ & $3.29 \pm 0.01^{\mathrm{a}}$ & $4.31 \pm 0.42$ \\
\hline Stand density (stems ha ${ }^{-1}$ ) & $1567 \pm 188^{\mathrm{a}}$ & $1446 \pm 97^{\mathrm{a}}$ & $891 \pm 245^{\mathrm{b}}$ & $1313 \pm 113^{\mathrm{ab}}$ & $1304 \pm 118$ \\
\hline $\mathrm{BA}\left(\mathrm{m}^{2} \mathrm{ha}^{-1}\right)$ & $5.90 \pm 0.63^{\mathrm{a}}$ & $11.74 \pm 0.93^{\mathrm{a}}$ & $10.11 \pm 3.20^{\mathrm{a}}$ & $5.84 \pm 3.78^{\mathrm{a}}$ & $8.39 \pm 1.61$ \\
\hline Complexity index (CI) & 0.95 & 2.26 & 1.52 & 0.76 & 1.71 \\
\hline
\end{tabular}

* Values are mean \pm standard error. Same superscript letter notation in each row shows no significance difference between sub-sites.

polygons representing the identified classes. Before the classifications, we examined the spectral separability between all pairs of training ROIs using the transformed divergence separability index (Richards and Xiuping, 1999). Values of this index range from 0 to 2, with 2 indicating $100 \%$ separation. The maximum likelihood classification method was later done on the three images, and confusion matrices were calculated to obtain producer's and user's accuracies and the subsequent overall classification accuracy. We only performed accuracy assessments on the 2009 image since the GCPs were collected in 2011 and no significant change was notable in the period between these two years. We used the 1992 vector map as the baseline year to calculate species loss/gain till 2009 and overall mangrove cover change between 1994, 2000 and 2009. Maps on cover change were used to display the variation on mangrove vegetation areal extent based on maps for 1992 and 2009.

\subsubsection{Statistical analysis}

All variables were subjected to a normality test using the Kolmogrov-Smirnov test; subsequently, structural parameters - mean height, mean DBH, stand density, and BA were subjected to analysis of variance for mean comparison among sub-sites within each creek and Tukey's honest significant difference (HSD) multiple comparison test was adopted for mean separation if the main effects were significant. Statistical differences in these structural variables between Mwache and Tudor creeks were examined using Welch's $t$ test. All statistical analyses were conducted using R 2.14.1 environment for statistical computing (R Development Core Team, 2011).

\section{Results and discussion}

\subsection{Stand structural characteristics and spatial variability}

The structural attributes describing the mangrove vegetation in Tudor and Mwache creeks are summarized in Table 1. In Mwache, five species were encountered in both the adult canopy and juveniles, whereas in Tudor, five species were encountered but four species were represented at both the adult and juvenile stages. Bruguiera gymnorrhiza (L.) Lamk. occurred only at juvenile stages, and no juveniles of $S$. alba were encountered in Tudor Creek contrary to what was observed in Mwache Creek.

Mangrove vegetation in Tudor and Mwache creeks differed significantly in mean tree diameter, DBH $(t=9.42$, $p<0.001)$ and mean height $(t=12.75, p<0.001)$. In Tudor, mean tree DBH varied significantly among sub-sites within creek $(F=8.489, p<0.001)$, ranging from 3.29 to $7.75 \mathrm{~cm}$, and mean height also varied significantly within the creek $(F=9.975, p<0.001)$, with values ranging from 3.29 to $5.45 \mathrm{~m}$, with the maximum recorded DBH and height being $60.50 \mathrm{~cm}$ and $15.00 \mathrm{~m}$ respectively. In Mwache, the mean DBH range was higher than in Tudor, ranging from $6.40 \mathrm{~cm}$ to $12.95 \mathrm{~m}$, and significantly different $(F=23.26$, $p<0.001)$ among sub-sites within the creek; and the mean tree height also differed significantly $(F=22.2, p<0.001)$. The maximum DBH and height recorded in Mwache was $53.0 \mathrm{~cm}$ and $15.00 \mathrm{~m}$ respectively. The graphical comparison of mean height and mean DBH of adult trees encountered across the creeks is presented in Fig. 2. The pattern is similar for both mean height and mean DBH, with no significant 

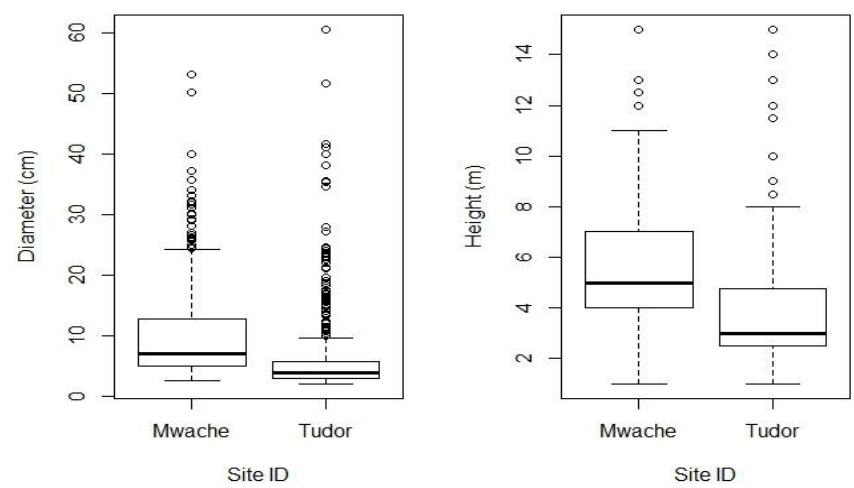

Fig. 2. Diameter and height distribution in Tudor and Mwache creeks.

difference except that they were both higher in the Islands zone.

Diameter distribution followed mostly the inverse-J shape, which is typical of naturally regenerating forests, but with a slight deviation as some size classes are devoid of any individuals especially in Tudor Creek. It is apparent that Tudor Creek is vigorously regenerating with most of the stems being $<5 \mathrm{~cm}$. Overall, trees of diameter class $5.0-7.0 \mathrm{~cm}$ were not overexploited compared to those of diameter class 7.0$9.0 \mathrm{~cm}$, which were more utilized in Mwache Creek (Fig. 3). The trees in the higher size classes were low in both creeks as expected of natural/uneven-aged stands.

Based on the IV presented in Fig. 4, R. mucronata and A. marina were the dominant species in Tudor Creek, whereas $R$. mucronata and $S$. alba are the dominant species in Mwache Creek. Also, there exists some spatial variability in species dominance across different locations, with the dominance of S. alba on the islands being noteworthy as compared to other locations.

\subsection{Regeneration patterns of juvenile mangrove species in Tudor Creek}

Juveniles had a varying distribution pattern across the study area depending on site. Most of the juveniles were found landward compared to the seaward sites. $R$. mucronata, $A$. marina and $C$. tagal appeared to be rejuvenating in most parts of the creeks (Table 2). The highest regeneration occurred for A. marina (9200 juveniles $\mathrm{ha}^{-1}$ ) and $R$. mucronata (4190 juveniles ha ${ }^{-1}$ ) in Tudor, while $R$. mucronata (7016 juveniles $\mathrm{ha}^{-1}$ ) and C. tagal $\left(1025\right.$ juveniles ha $\left.{ }^{-1}\right)$ in Mwache, represented 83 and $12 \%$ respectively of all juveniles encountered. The least was for $B$. gymnorrhiza at both sites representing less than $1 \%$ of the whole creek's juveniles. The juveniles for S. alba were scanty and were only represented as RCIII in Mwache but were entirely absent in Tudor despite their presence in the adult canopy.
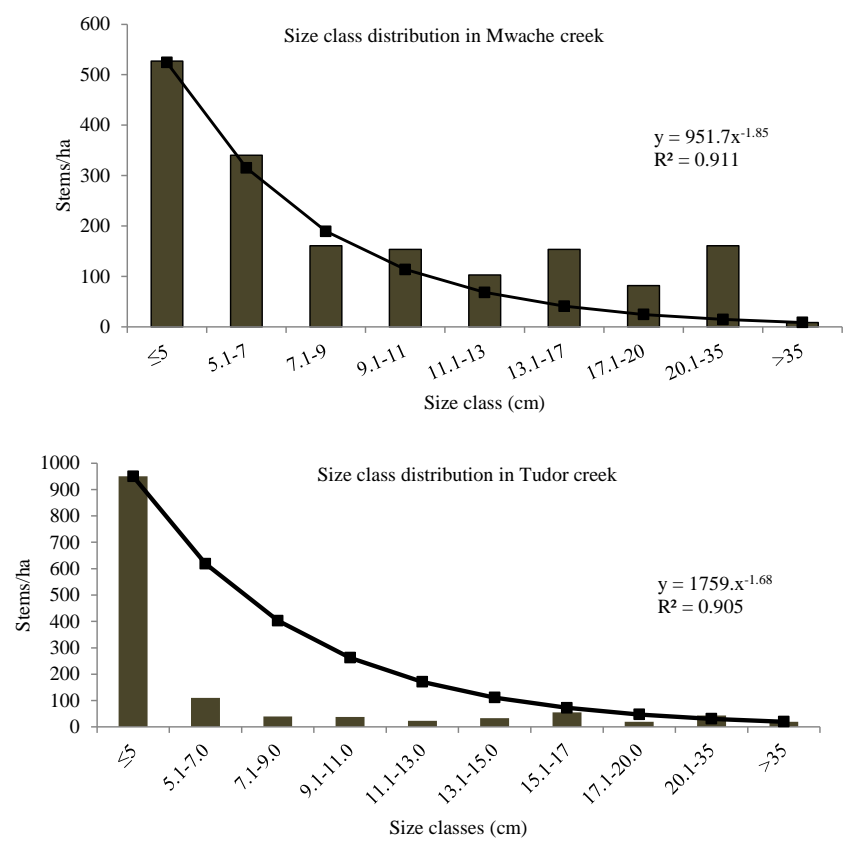

Fig. 3. Size class distribution.

\subsection{Mangrove extent and cover change}

The overall classification accuracy for the 2009 image was $80.23 \%$ and Cohen's kappa of 0.77 , showing satisfactory results for its use in this context (Table 3). Change in areal extent of mangrove forest in Tudor and Mwache creeks is summarized in the matrix provided in Table 4 . It depicts mangrove loss with subsequent years. In 2009 the forest cover had reduced to 215.3 ha for Tudor and 1016.9 ha for Mwache from a cover of 1641.3 and 1861.4 ha in 1992 respectively. This was a loss of 1425.0 and 844.5 ha of mangrove cover from 1992 (Fig. 5), representing 86.5 and $45.4 \%$ less cover respectively. The highest rate of cover loss was between 2000 and 2009, which was -73.68 and $-20.04 \%$ for Tudor and Mwache creeks respectively. Change in the area covered by individual species is provided in Table 4 and Fig. 6. In Tudor Creek, four species were observed in 1992 and five for Mwache Creek, but they had reduced to four in 2009 with no complete loss of any species in the former. The most affected species was Xylocarpus granatum Koenig, 1784, which had a cover of 13.11 ha in 1992 but was not observed in 2009.

Rhizophora mucronata and $C$. tagal had also suffered drastic losses in both creeks (Table 5). Avicennia marina reduced in cover by $40.5 \%$ in Tudor Creek contrary to its increase by $115.6 \%$ in Mwache Creek. However, S. alba was greatly increased in cover by $1199 \%$ in Mwache compared to $137.4 \%$ in Tudor Creek. 
Table 2. Juvenile density in forests within the study area.

\begin{tabular}{|c|c|c|c|c|c|}
\hline \multirow[b]{2}{*}{ Sites } & \multirow[b]{2}{*}{ Species } & \multicolumn{2}{|c|}{ Regeneration class } & \multirow[b]{2}{*}{ RCIII } & \multirow[b]{2}{*}{ Total $\left(\mathrm{ha}^{-1}\right)$} \\
\hline & & RCI & RCII & & \\
\hline \multirow{6}{*}{ Mwache } & A. marina & $285 \pm 161(95)$ & $11 \pm 8(4)$ & $4 \pm 4(1)$ & $300(4)$ \\
\hline & B. gymnorrhiza & $16 \pm 16(73)$ & $4 \pm 4(20)$ & $1 \pm 1(7)$ & $22(<1)$ \\
\hline & C. tagal & $501 \pm 273(49)$ & $355 \pm 169(35)$ & $168 \pm 83(16)$ & $1025(12)$ \\
\hline & R. mucronata & $2503 \pm 479(36)$ & $2279 \pm 445(32)$ & $2234 \pm 495(32)$ & $7016(83)$ \\
\hline & S. alba & $0(0)$ & $22 \pm 22(30)$ & $51 \pm 30(70)$ & $72(1)$ \\
\hline & Total $\left(\mathrm{ha}^{-1}\right)$ & 3306 (39) & $2672(32)$ & 2459 (29) & $8436(100)$ \\
\hline \multirow{5}{*}{ Tudor } & A. marina & $8876 \pm 701(96)$ & $107 \pm 05(1)$ & $217 \pm 16(2)$ & $9200(66)$ \\
\hline & B. gymnorrhiza & 0 & 0 & $34(100)$ & $34(<1)$ \\
\hline & C. tagal & $146 \pm 33(27)$ & $207 \pm 47(39)$ & $183 \pm 07(34)$ & $537(4)$ \\
\hline & R. mucronata & $646 \pm 04(15)$ & $1080 \pm 08(26)$ & $2463 \pm 11(59)$ & $4190(30)$ \\
\hline & Total $\left(\mathrm{ha}^{-1}\right)$ & $9668(69)$ & $1395(10)$ & $2898(21)$ & $13961(100)$ \\
\hline
\end{tabular}

a Values are mean \pm standard error. ${ }^{b}$ The values in parenthesis in a row represent the percentage of the total juveniles of a species in the different regeneration classes.

Table 3. Classification accuracy for the 2009 image based on the different classes delineated.

\begin{tabular}{lrr}
\hline Class & $\begin{array}{r}\text { Producer's } \\
\text { accuracy }\end{array}$ & $\begin{array}{r}\text { User's } \\
\text { accuracy }\end{array}$ \\
\hline Sonneratia alba & 78.09 & 86.67 \\
Ceriops tagal & 78.1 & 72.89 \\
Avicennia marina & 79.56 & 67.73 \\
Rhizophora mucronata & 87.5 & 94.94 \\
Sand/sandy beaches & 73.37 & 96.82 \\
Water & 93.34 & 99.99 \\
Mud & 58.08 & 76.66 \\
Open mangrove areas & 93.83 & 100 \\
\hline Overall accuracy & $80.23 \%$ & \\
K coeff. & 0.77 & \\
\hline
\end{tabular}

\subsection{Discussion}

This study purposed to investigate the hypothesis that periurban mangroves are experiencing higher degradation rates far exceeding the global mean of 1-2\% pa commonly reported in the literature, using the Mombasa mangroves in Kenya as a case study. Additionally, a recent study by Kirui et al. (2013) had indicated that Kenyan mangroves had lost only $20 \%$ cover over a period of 25 years, representing a $0.74 \%$ annual loss. We sought to investigate whether peri-urban mangroves are experiencing a much higher degradation rate than this national average as well, which could have significant management implications. Emch and Peterson (2006) described changes in mangrove forests as multidimensional, resulting from biotic, geomorphic and anthropogenic influences. Although it is difficult to isolate the singular effect of each factor in a complex mangrove system, it is speculated that massive degradation in the study areas can be linked to
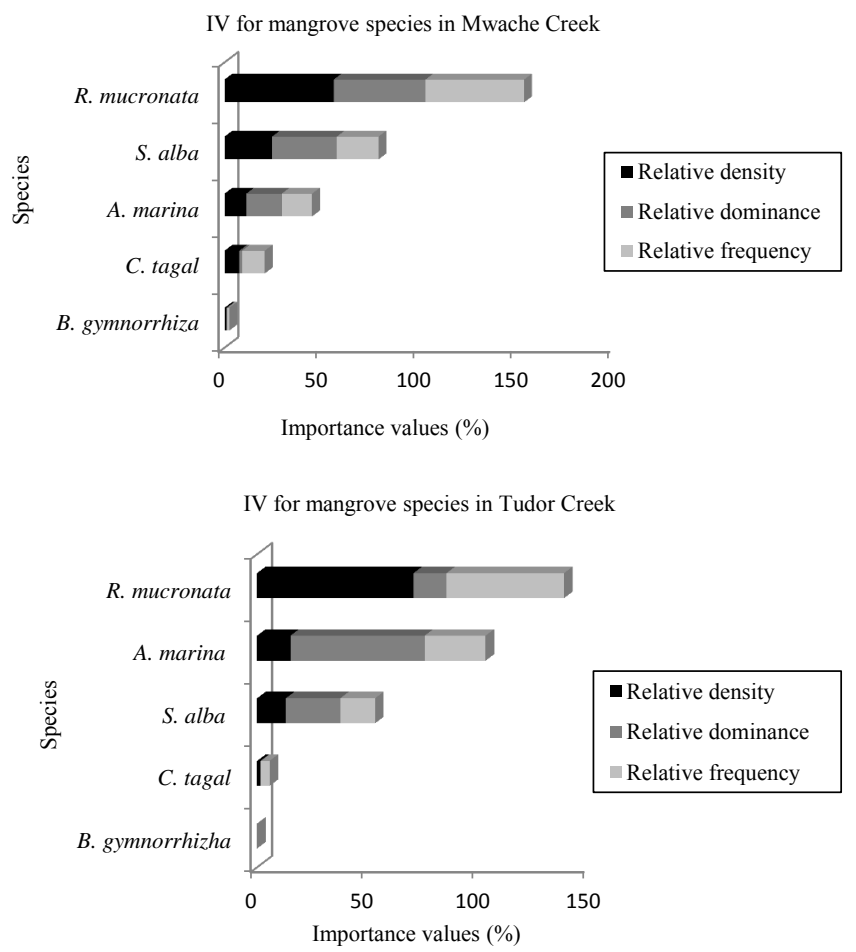

Fig. 4. Importance values for the various species in Mwache and Tudor creeks.

mangrove response to man-induced stressors in combination with indirect impacts of climate change and variability.

Analyses of forest structure and temporal changes in mangrove cover strongly suggested that the mangrove forests in Tudor and Mwache creeks have been severely degraded. These peri-urban forests experienced a cover loss of 86.9 and $45.4 \%$ for Tudor and Mwache respectively over the 17year period, with the highest loss occurring between 2000 
Table 4. Mangrove cover change over the years.

\begin{tabular}{llrrrr}
\hline Site & Variables & \multicolumn{4}{c}{ Time series } \\
\cline { 3 - 6 } & & 1992 & 1994 & 2000 & 2009 \\
\hline \multirow{3}{*}{ Mwache } & Areal extent $\left(\mathrm{ha}^{-1}\right)$ & 1861.4 & 1536.2 & 1271.9 & 1016.9 \\
& Cover loss $\left(\mathrm{ha}^{-1}\right)$ & - & -325.2 & -589.6 & -844.5 \\
& Percentage cover & - & -17.5 & -31.7 & -45.4 \\
& change against 1992(\%) & & & & \\
\hline \multirow{3}{*}{ Tudor } & Areal extent (ha $\left.{ }^{-1}\right)$ & 1641.3 & 1281.4 & 818.1 & 215.3 \\
& Cover loss (ha $\left.{ }^{-1}\right)$ & - & -359.9 & -823.2 & -1426.1 \\
& Percentage cover & - & -21.95 & -50.2 & -86.9 \\
& change against 1992 (\%) & & & & \\
\hline
\end{tabular}

Table 5. Species cover change in 1992 and their shift in 2009.

\begin{tabular}{llrrr}
\hline Site & Species & \multicolumn{3}{c}{ Year } \\
\cline { 3 - 5 } & & 1992 & 2009 & \% change \\
\hline \multirow{6}{*}{ Mwache } & Avicennia marina & 171.6 & 370.1 & +115.6 \\
& Ceriops tagal & 685.5 & 192.1 & -72.0 \\
& Rhizophora mucronata & 978.3 & 287.4 & -70.6 \\
& Sonneratia alba & 12.9 & 167.4 & +1199.0 \\
& Xylocarpus granatum & 13.1 & 0 & -100 \\
\hline \multirow{6}{*}{ Tudor } & Avicennia marina & 110.8 & 65.9 & -40.5 \\
& Ceriops tagal & 252.4 & 38.1 & -84.9 \\
& Rhizophora mucronata & 1244.2 & 30.6 & -97.5 \\
& Sonneratia alba & 33.9 & 80.6 & +137.4 \\
\hline
\end{tabular}

and 2009. This decadal (2000-2009) loss was higher in Tudor $(-73.68 \%)$ compared to Mwache Creek $(-20.04 \%)$ and can be attributed to indiscriminate and uncontrolled harvesting. Illegal encroachment on the mangrove forests was evident especially in Tudor, which has exacerbated extractive pressure due to high dependency on wood fuel as the main source of energy at the coast and in the country in general (Dahdouh-Guebas et al., 2000). During the field study in Tudor forest, we observed lots of illicit distillers for local brew business, which wholly depends on mangroves as a source of fuelwood. Additionally, massive sedimentation due to poor land-use practices upstream aggravated by episodic intense precipitation during short rains (Kitheka et al., 2002; Omar et al., 2008) contributed to this loss. It was within this period that the IOD events of 1997-1998 and 2006 occurred causing massive destruction of these forests through water impounding and sedimentation. This concurs with other studies done on mangrove cover in Kenya (Bosire et al., 2008; Bosire, 2010; Kirui et al., 2013).

From the size class distribution figures, we can deduce selective wood harvesting in Mwache compared to indiscriminate harvesting in Tudor Creek. This has left gaps in the forest, which explains the high regeneration especially for R. mucronata, which is shade intolerant (Ellison and Farnworth, 1993), in Tudor Creek compared to Mwache, where mature stands were encountered in some parts of the creek. The size class distribution in Mwache obeys the expected reversed $\mathbf{J}$ pattern typical of uneven-aged regenerating natural stands, while the pattern in Tudor is indicative of unusually high extractive pressure which targets all classes. This suggests that while the drivers of change among the two creeks may be similar, the scale and magnitude is substantially different. The insignificant difference in complexity indices between mangrove forests in both creeks (1.80 and 1.71 for Mwache and Tudor creeks respectively) however showed no conspicuous variability in structural complexity of the two creeks. From the size class distribution for instance, Tudor Creek is portrayed as an overly degraded and young forest compared to Mwache Creek. These human modifications within the coastal zone will reduce the resilience of these ecosystems, making them more vulnerable to climatechange-related phenomena, e.g. flooding and sedimentation (Ellison and Farnsworth, 1996a; Kitheka et al., 2002; Mckee et al., 2007; Lovelock and Ellison, 2007; Bosire, 2010). Interestingly and on a more positive note, natural regeneration in the creeks was substantially higher and more vigorous than the minimum recommended of 2500 seedlings $\mathrm{ha}^{-1}$ (FAO, 1994) for successful forest re-stocking, thus suggesting that natural recovery may be possible if current anthropogenic pressures are moderated. 


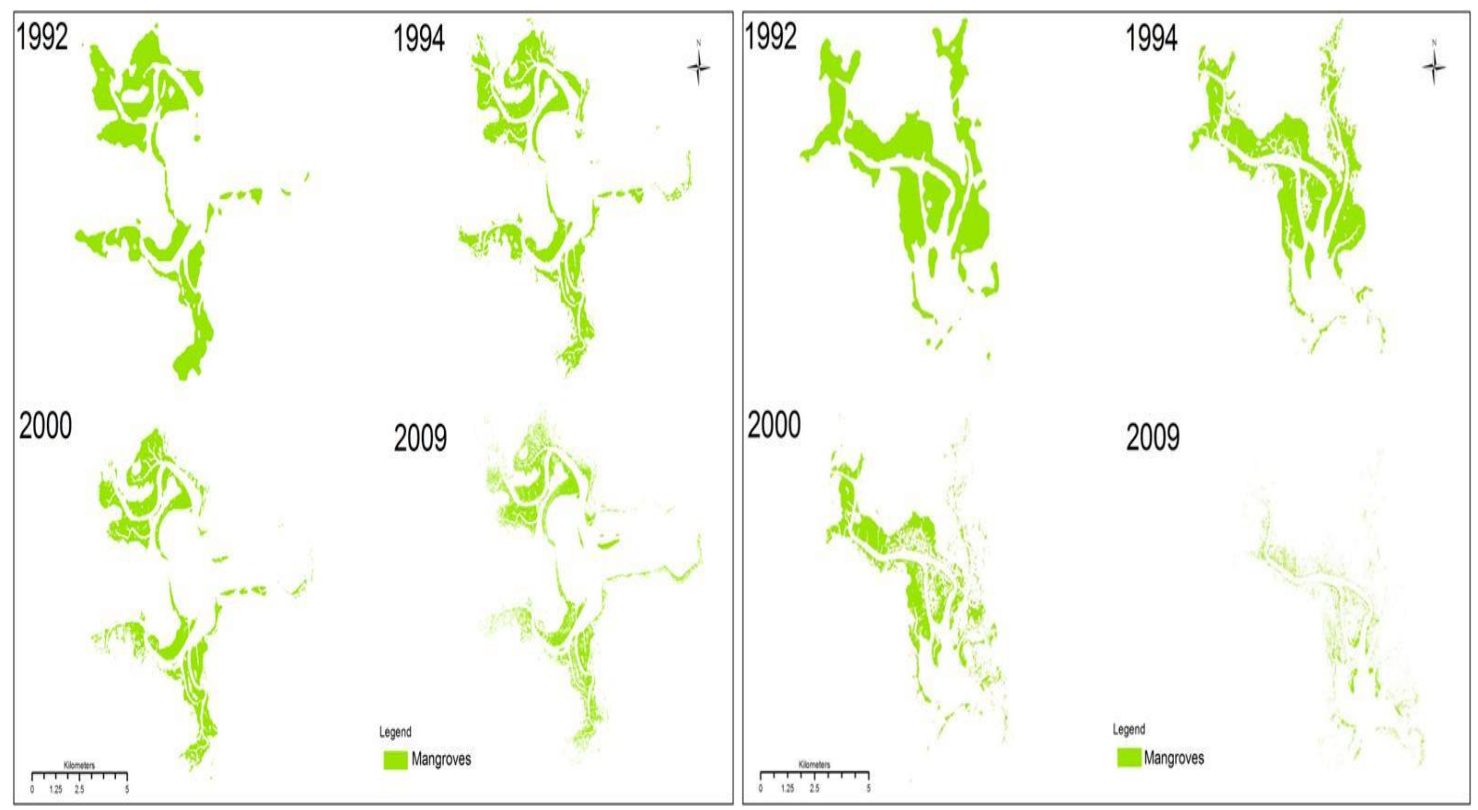

Fig. 5. Forest cover change from 1992 to 2009 in Mwache and Tudor creeks respectively.

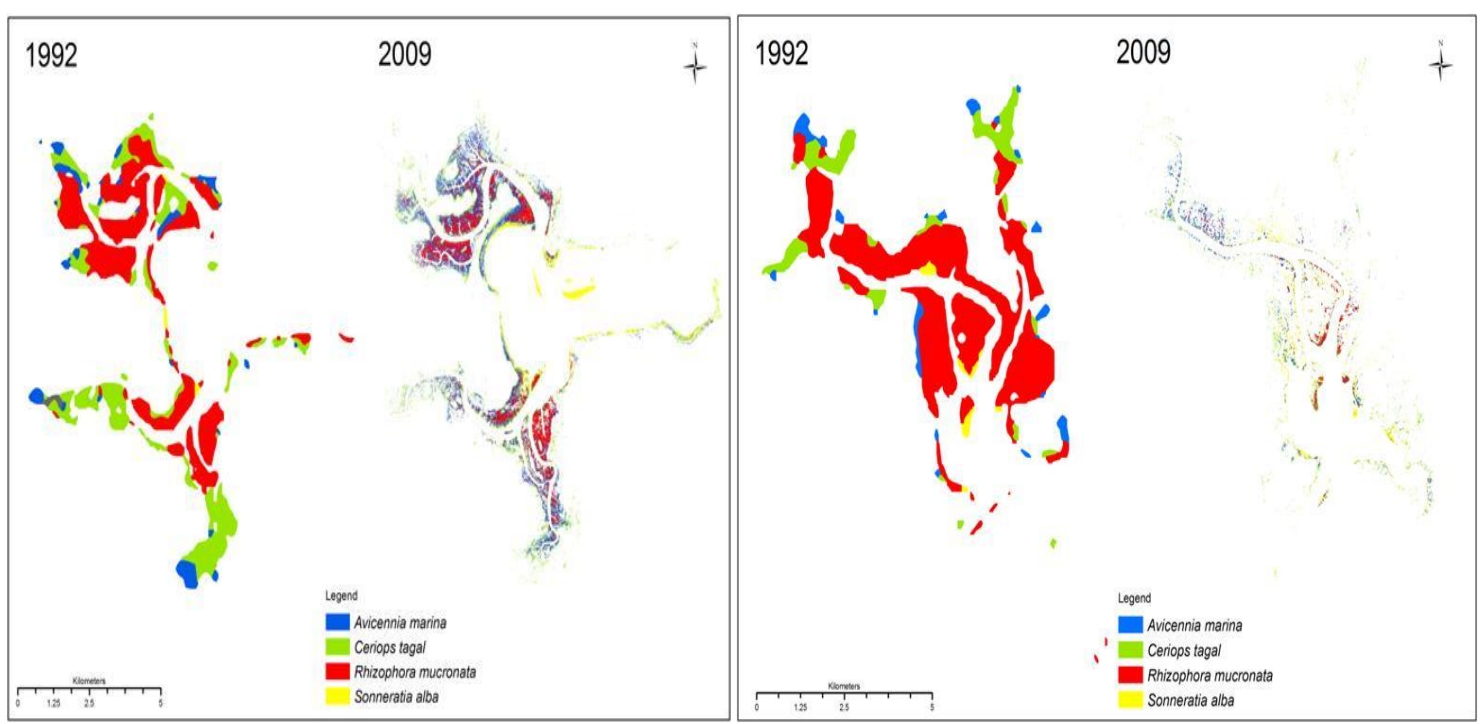

Fig. 6. Species shift between 1992 and 2009 in Mwache and Tudor creeks respectively.

The structural attributes reported here are much lower than those of mangrove stands in other parts of the country, a fact attributable to the inordinate pressure experienced by the peri-urban mangroves in this study. For instance mangroves of the northern part of Kenya, in Lamu (stand density of 2075-2142 stems ha ${ }^{-1}$, basal area of $24.5-46.97 \mathrm{~m}^{2} \mathrm{ha}^{-1}$, and canopy height of 16-26.5 m; Kairo et al., 2001), are much more developed than the mangroves of the current study area. The mangroves of the southern coast of Kenya are also more developed with stem densities ranging 1573 1839 stems ha $^{-1}$; mean height 6-7.4 m; and basal area 9.7-
$13 \mathrm{~m}^{2} \mathrm{ha}^{-1}$ (unpublished data). The south and north of Kenya mangroves are distant from Mombasa and thus under less extractive pressure as these areas are less populated.

Sonneratia alba, which is a pioneer species, has thrived in both creeks, with its coverage increasing by more than $100 \%$ over the period under consideration. This species is adapted to long periods of inundation and was thus not impacted significantly during the IOD event. Continued sedimentation, while a major threat to the mangroves within the study area in general, has led to the creation of suitable conditions for pioneer species, hence the establishment of new islands 
(Fig. 5a). Avicennia marina coverage has also increased in the creeks owing to its tolerance to a wide range of environmental conditions (Wells, 1982; Clarke, 1995; DadouhGuebas et al., 2004; Huisman et al., 2009; Wang'ondu et al., 2010). However, $R$. mucronata and $C$. tagal, normally most preferred by the locals for their quality and diverse uses, have dwindled significantly over the years. The stumps observed in the current study were both old, and recent cuttings largely belonging to these two species. Severely reduced density of standards (parent trees) may compromise propagule production and thus limit natural regeneration (Bosire et al., 2003, 2008). Avicennia marina has overtaken $R$. mucronata in terms of cover in Mwache Creek over the years, raising questions of whether in the long-term there may be species shifts in the canopy; but this is unlikely since $R$. mucronata comprises $83 \%$ of the juvenile density and is thus likely to play a major role in future forest re-stocking, still almost guaranteeing its continued dominance in the adult stratum.

An annual cover loss of $5.1 \% \mathrm{yr}^{-1}$ estimated in Tudor mangrove forest is distinctively higher than that of Mwache Creek $\left(2.7 \%^{-1}\right)$. These losses were significantly higher compared to the average of $0.7 \%$ pa recently estimated for Kenyan mangrove forests (Kirui et al., 2013) and the 1$2 \%$ global degradation rate of mangrove forests (Giri et al., 2011). These unprecedentedly high degradation rates, which far exceed not only the national mean but the global mean as well, strongly suggest that these mangroves are highly threatened due the compounded pressures already discussed. For instance in Tudor Creek, only 215.3 ha of mangroves are remaining from a cover of 1642.3 ha in a span of less than 20 years. The majority of the studies that have been conducted previously on mangrove cover change are at a country or global level. The current study has narrowed mangrove cover loss to a specific impacted zone, which makes it easier for forest managers to allocate resources based on the acquired data of high resolution at species level degradation and rejuvenation. This provides a baseline on which species may be used as candidates for restoration before their extinction and which species can be used to improve upon the forest cover on bare sites based on their suitability to colonize degraded areas or withstand different and harsh environmental conditions as "smart species". Strengthening of governance regimes through enforcement and compliance to halt illegal wood extraction, improvement of land-use practices upstream to reduce soil erosion, restoration in areas where natural regeneration has been impaired, provision of alternative energy sources/building materials, and a complete moratorium on wood extraction especially in Tudor Creek to allow recovery are some of the suggested management interventions.

Acknowledgements. The study was funded by the Western Indian Ocean Marine Science Association (WIOSMA) under the MASMA Regional Project on "Resilience of mangroves and dependent communities in the WIO region to climate change", Grant No: MASMA/CC/2010/08. We sincerely thank Planet Action for supporting the project through provision of SPOT images for spatial-temporal analysis. The effort of KMFRI colleagues: Alfred Obinga, George Onduso, Richard Angwenyi and Erick Okenagwa is much appreciated.

Edited by: B. Satyanarayana

\section{References}

Allen, J. A., Ewel, K. C., and Jack, J.: Patterns of natural and anthropogenic disturbance of the mangrove on the Pacific Island of Kosrae, Wetlands Ecol. Manage., 9, 279-289, 2001.

Alongi, D. M.: Present state and future of the world's mangrove forests, Environ. Conservat., 29, 331-349, 2002.

Alongi, D. M.: Mangrove forests: resilience, protection from tsunamis, and responses to global climate change, Estuarine, Coast. Shelf Sci., 76, 1-13, 2008.

Ardli, E. R. and Wolff, M.: Land use and land cover change affecting habitat distribution in the Segara Anakan lagoon, Java, Indonesia, Reg. Environ. Change, 9, 235-243, 2009.

Aschbacher, J., Ofren, R., Delsol, J. P., Suselo, T. B., and Vibulsresth, S.: An integrated comparative approach to mangrove vegetation mapping using advanced remote sensing and GIS technologies: preliminary results', Hydrobiologia, 295, 285-294, 1995.

Blasco, F., Lavenu, F., and Baraza, J.: Remote sensing data applied to mangroves of Kenya coast. Proceedings of the 20th International Symposium on Remote Sensing of the Environment, 3, 1465-1480, 1986.

Blasco, F., Janodet, E., and Bellan, M. F.: Impacts of coastal hazards on mangroves in the Bay of Bengal, J. Coastal Res., 12, 277-288, 1994.

Bond, I., Grieg-Gran, M., Wertz-Kanounnikoff, S., Hazlewood, P., Wunder, S., and Angelsen, A.: Incentives to sustain forest ecosystem services: A review and lessons for REDD. Natural Resource Issues No. 16. International Institute for Environment and Development, London, UK, with CIFOR, Bogor, Indonesia, and World Resources Institute, Washington DC, USA, 2009.

Bosire, J. O.: Resilience of mangroves impacted by indirect effects of global climate change, A preliminary assessment report No: WIOMSA/MARG-1/2010-12, 2010.

Bosire, J. O., Dahdouh-Guebas, F., Kairo, J. G., and Koedam, N.: Colonization of non-planted mangrove species into restored mangrove stands in Gazi Bay, Kenya, Aquat. Bot., 76, 267-279, 2003.

Bosire, J. O., Kairo, J. G., Kazungu, J., Koedam, N., and DahdouhGuebas, F.: Predation on propagules regulates regeneration in a high-density reforested mangrove plantation, Mar. Ecol. Prog. Ser., 299, 149-155, 2005.

Bosire, J. O., Dahdouh-Guebas, F., Kairo, J. G., Wartel, S., Kazungu, J., and Koedam, N.: Success rates of recruited tree species and their contribution to the structural development of reforested mangrove stands, Mar. Ecol. Prog. Ser., 325, 85-91, 2006.

Bosire, J. O., Dahdouh-Guebas, F., Walton, M., Crona, B. I., Lewis, R., Field, C., Kairo, J. G., and Koedam, N.: Functionality of re- 
stored mangroves, Special Issue of Aquatic Botany, 89, 251-259, 2008.

Bosire, J. O., Bandeira, S., and Rafael, J.: Coastal climate change mitigation and adaptation through REDD+ carbon programs in mangroves in Mozambique: Pilot in the Zambezi Delta. Determination of carbon stocks through localized allometric equations component, WWF 27 pp., 2012.

Chaudhury, M. U.: Digital analysis of remote sensing data for monitoring the ecological status of the mangrove forests of Sunderbans in Bangladesh. Proceedings of the 23rd International Symposium on Remote Sensing of the Environment, 1, 493-497, 1990.

Cintron, G. and Schaeffer-Novelli, Y.: Methods for studying mangrove structure, in: The mangrove ecosystem: research methods, edited by: Snedaker, S. C. and Snedaker, J. G., UNESCO, Paris, France, 91-113, 1984.

Clarke, P. J.: The population dynamics of the mangrove Avicennia marina: demographic synthesis and predictive modeling, Hydrobiologia, 295, 83-88, 1995.

Couwenberg, J., Dommain,, R., and Joosten, H.: Greenhouse gas fluxes from tropical peatlands in south-east Asia, Glob. Chall. Biology, 16, 1715-1732, 2010.

Dahdouh-Guebas, F., Mathenge, C., Kairo, J. G., and Koedam, N.: Utilization of mangrove wood products around Mida Creek (Kenya) amongst subsistence and commercial users, Econom. Botany, 54, 513-527, 2000.

Dahdouh-Guebas, F., De Bondt, D., Abeysinghe, P. D, Kairo, J. G, Cannicci, S., Triest, L., and Koedam, N.: Comparative study of the disjunct zonation pattern of the grey mangrove Avicennia marina (forsk.) vierh. in: Gazi bay (Kenya), Bull. Mar. Sci., 74, 237-252, 2004

Dale, P. E. R., Chandica, A. L., and Evens, M.: Using image substraction and classi?cation to evaluate change in subtropical intertidal wetlands, Int. J. Remote Sens., 17, 703-719, 1996.

Donato, D. C., Kauffman, J. B., Murdiyarso, D., Kurnianto, S., and Stidham, M.: Mangroves among the most carbon-rich tropical forests and key in landuse carbon emissions, Nature Geosci., 4, 293-297, 2011.

Duke, N. C., Meynecke, J. O., Dittmann, A. M., Ellison, A. M., Aanger, K., Berger, U., Cannicci, S., Diele, K., Ewel, K. C., Field, C. D., Koedam, N., Lee, S. Y., Marchand, C., Nordhaus, I., and Dahdouh-Guebas, F.: A world without mangroves?, Science, 317, 41-42, 2007.

Ellison, A. M. and Farnsworth, E. J.: Seedling survivorship, growth and response to disturbance in Belizean mangal, Ame. J. Botany, 80, 1137-1145, 1993.

Ellison, A. M. and Farnsworth, E. J.: Anthropogenic disturbance of Caribbean mangrove ecosystems: past impacts, present trends, and future predictions, Biotropica, 28, 549-565, 1996a.

Ellison, J. C. and Stoddart, D. R.: Mangrove ecosystem collapse during predicted sea level rise: Holocene analogues and implications, J. Coast. Res., 7, 151-165, 1991.

Emch, M. and Peterson, M.: Mangrove Forest Cover Change in the Bangladesh Sundarbans from 1989-2000: A Remote Sensing Approach, Geocarto International, 21, 5-12, 2006.

Ezzine-de-Blas, D., Borner, J., Violato-Espada, L., Nascimento, N., and Piketty, M.: Forest loss and management in land reform settlements: Implications for REDD governance in the Brazilian Amazon, Environ. Sci. Policy, 14, 188-200, 2012.
FAO: Conservation and Management of Mangroves-Kenya, Terminal report FO:TCP/KEN/0051, FAO, Rome, 18 pp., 1992.

FAO: Mangrove Forest Management Guidelines, FAO Forestry Paper 117, FAO, Rome, 350 pp., 1994.

Gallin, E., Coppejans, E., and Beeckman, H.: The mangrove vegetation of Gazi Bay (Kenya). Bull. Soc. Roy. Belg., 122, 197-207, 1989.

Gang, P. O. and Agatsiva, J. L.: The current status of mangroves along the Kenyan coast: a case study of Mida creek mangroves based on remote sensing', Hydrobiologia, 247, 29-36, 1992.

Gao, J.: A hybrid method toward accurate mapping of mangroves in a marginal habitat from SPOT multispectral data, Int. J. Remote Sens., 19, 1887-189, 1998.

Gilman, E., Ellison, J., Duke, N. C., and Field, C.: Threats to mangroves from climate change and adaptation options: a review, Aquatic Botany, 89, 237-250, 2008.

Giri, C., Ochieng, E., Tieszen, L. L., Zhu, Z., Singh, A., Loveland, T., and Duke, N. C.: Status and distribution of mangrove forest of the world using earth observation satellite data, Glob. Ecol. Biogeogr., 20, 154-159, 2011.

Government of Kenya: Kenya State of the Coast Report: towards the integrated management of Kenya's coastal and marine resources, UNEP and NEMA, Nairobi, 90 pp., 1999.

Green, E. P., Mumby, P. J., Edwards, A. J., Clark, C. D., and Ellis, A. C.: The assessment of mangrove areas using high resolution multispectral airborne imagery, J. Coast. Res., 14, 433-443, 1998.

Hauff, R. D., Ewel, K. C., and Jack, J.: Tracking human disturbance in mangroves: estimating harvest rates on a Micronesian Island, Wetlands Ecol. Manage., 14, 95-105, 2006.

Holdridge, L., Grenke, W. C., Hatheway, W. H., Liang, T., and Tosi, J. A.: Forest Environment in Tropical Life Zones, Pergamon Press, New York, 747 pp., 1971.

Huisman, T. J., Van Langevelde, F., and De Boer, W. F.: Local positive feedback and the persistence and recovery of fringe Avicennia marina (Forssk.) vierh. mangroves, Wetlands Ecol. Manage., 17, 601-611, 2009

IPCC: Climate change synthesis report, A report of the Intergovernmental Panel on Global Climate Change, 2007.

Jensen, J. R., Ramset, E., Davis, B. A., and Thoemke, C. W.: The measurement of mangrove characteristics in south-west Florida using SPOT multispectral data, Geocarto Int., 2, 13-21, 1991.

Kairo, J. G.: Ecology and restoration of mangrove systems in Kenya, Ph.D. Thesis. Laboratory of Plant Sciences and Nature Management, University of Brussels (VUB), Belgium, 2001.

Kairo, J. G., Dahdouh-Guebas, F., Gwada, P. O., Ochieng, C., and Koedam, N.: Regeneration status of mangrove forests in Mida Creek, Kenya: a compromised or secured future?, Ambio, 31, 562-568, 2002.

Kayanne, H., Iijima, H., Nakamura, N., McClanahan, T., Behera, S., and Yamagata, T.: Indian Ocean Dipole index recorded in Kenyan coral annual density bands, Geophys. Res. Lett., 33, L19709, doi:10.1029/2006GL027168, 2006.

Kindt, R. and Coe, R.: Tree diversity analysis, A manual and software for common statistical methods for ecological and biodiversity studies, World Agroforestry Centre (ICRAF), Nairobi, ISBN 92-9059-179-X., 2005.

Kirui, B. K., Kairo, J. G., Bosire, J. O., Viergever, K. M., Rudra, S. Huxham, M., and Briers R. A.: Mapping of mangrove forest land 
cover change along the Kenya coastline using Landsat imagery, Oc. Coast. Manage., 30, 1-6, 2013.

Kitheka, U. J., Ongwenyi, S. G., and Mavuti, M. K.: Dynamics of suspended sediment exchange and transport in a degraded mangrove creek in Kenya, Ambio, 31, 580-587, 2002.

Long, B. G. and Skewes, T. D.: GIS and remote sensing improves mangrove mapping. 7th Australian Remote Sensing Conference, 1-4 March 1994, Melbourne, Australia, 1, 545-551, 1994.

Lovelock, E. C. and Ellison, J.: Vulnerability of mangroves and tidal wetlands of the Great Barrier Reef to climate change, Chapter 9: Species and Species group, 2007.

Lugo, A. E. and Snedaker, S. C.: The ecology of mangroves, Ann. Rev. Ecol. Systemat., 5, 39-64, 1974.

Macnae, W.: A general account of the fauna and flora of mangrove swamps and forests in the Indo - West Pacific region. Adv. Mar. Bio., 6, 72-270, 1968.

Marchant, R., Mumbi, C., Behera, S. K., and Yamagata, T.: The Indian Ocean Dipole - the unsung driver of climatic variability in East Africa, Afr. J. Ecol., 45, 4-16, 2006.

McKee, K. L., Cahoon, D. R., Feller, I.: Caribbean mangroves adjust to rising sea level through biotic controls on change in soil elevation, Glob. Ecol. Biogeogr., 16, 545-556, 2007.

McLeod, E. and Salm, R. V.: Managing Mangroves for Resilience to Climate Change, IUCN, Gland, Switzerland, 64 pp., 2006.

Nagelkerken, I., Roberts, C. M., van der Velde, G., Dorenbosch, M., van Riel, M. C., Cocheret de la Morinière, E., and Nienhuis, P. H.: How important are mangroves and seagrass beds for coralreef fish?, The nursery hypothesis tested on an island scale, Mar. Ecol. Prog. Ser., 244, 299-305, 2002.

Nellemann, C., Corcoran, E., Duarte, C. M., Valdés, L., De Young, C., Fonseca, L., and Grimsditch, G. (Eds): Blue Carbon: A Rapid Response Assessment, United Nations Environment Programme, GRID-Arendal, 2009.

Omar, M., Neukermans, G., Kairo, J. G., Dahdouh-Guebas, F., and Koedam, K.: Mangrove forests in a peri-urban setting: the case of Mombasa (Kenya), Wetland Ecol. Manage., 17, 243-255, 2009.

Pillai, P. A. and Mohankumar, K.: Individual and combined influence of El Niño-Southern Oscillation and Indian Ocean Dipole on the Tropospheric Biennial Oscillation, Quart. J. Roy. Meteorol. Soc., 136, 297-304, 2010.

Reddy, C. S. and Roy, A.: Assessment of three decade vegetation dynamics in mangroves of Godavari Delta, India Using multitemporal satellite data and GIS, Res. J. Environ. Sci., 2, 108-115, 2008.

Richards, J. A. and Xiuping, J.: Remote Sensing Digital Image Analysis: An Introduction, 3rd edn Springer, New York: 1999.

Rönnbäck, P.: The ecological basis for economic value of seafood production supported by mangrove ecosystems, Ecol. Econom., 29: 235-252, 1999.
Ruwa, R. K.: Mangrove wetlands in Kenya, in: Wetlands of Kenya, Proceedings of a seminar on wetlands of Kenya, edited by: Crafter, S. A., Njuguna, S. G., and Howard, G. W., The IUCN Wetland Programme, 1992.

Saji, N. H., Goswami, B. N., Vinayachandran, P. N., and Yamagata, T.: A dipole mode in the tropical Indian Ocean, Nature, 401, 360363, 1999.

Saji, N. H., Xie, S. P., and Yamagata, T.: Tropical Indian Ocean variability in the IPCC twentieth-century climate simulations, J. Clim., 19, 4397-4417, 2006.

Sherman, E. S., Fahey, J. T., and Battles, J. J.: Small-scale disturbance and regeneration dynamics in a neotropical mangrove forest, J. Ecol., 88, 165-178, 2000.

Song, C., Woodcock, C. E., Seto, K. C., Pax-Lenney, M., and MaComber, S. A.: Classification and change detection using Landsat TM data: When and how to correct atmospheric effects?, Remote Sens. Environ., 75, 230-244, 2001.

Stoddard, C. H. and Stoddard, G. M.: Essentials of forestry practice, 4th Edn., John Wiley\&Sons, New York, 1987.

Sukardjo, S.: Natural regeneration status of commercial mangrove species (Rhizophora apiculata and Bruguiera gymnorrhiza) in mangrove forests of Tanjung Bungin, Bunyuasin District, South Sumatra, Forest Ecol. Manage., 20, 233-252, 1987.

Twilley, R. R., Rivera-Monroy, V. H., Chen, R., and Botero, L.: Adapting an ecological mangrove model to simulate trajectories in restoration ecology, Mar. Pollut. Bull., 37, 404-419, 1998.

Valiela, I., Bowen, J. L., and York, J.: Mangrove forests: one of the World's most threatened major tropical environment, BioScience, 51, 807-815, 2001.

Wang'ondu, V. W., Kairo, J. G., Kinyamario, J. I., Mwaura, F. B., Bosire, J. O., Dahdouh-Guebas, F., and Koedam, N.: Phenology of Avicennia marina (Forsk.) Vierh. in a disjunctly-zoned mangrove stand in Kenya, Western Indian Ocean J. Mar. Sci., 9, 135144, 2010.

Wells, A. G.: Mangrove vegetation of northern Australia, in: Mangrove ecosystem in Australia: structure, function and management, edited by: Clough, B. F., Australian National University Press, Canberra, 57-78, 1982.

Wieczkowski, J.: Tree mortality due to an El Niño flood along the lower Tana River, Kenya, African J. Ecol., 47, 56-62, 2009.

Yee, M.: REDD and BLUE Carbon: Carbon Payments for Mangrove Conservation, A Report on MAS Marine Biodiversity and Conservation (Capstone Project), 2010.

Zhang, K., Liu, H., Li, Y., Xu, H., Shen, J., Rhome, J., and Smith, T. J.: The role of mangroves in attenuating storm surges. Estuarine, Coast. Shelf Sci., 102/103, 11-23, 2012. 